\title{
The Metamorphic Rocks-Hosted Gold Mineralization At Rumbia Mountains Prospect Area In The Southeastern Arm Of Sulawesi Island, Indonesia
}

\author{
Hasria ${ }^{1,2^{*}}$, Arifudin Idrus ${ }^{1}$, I Wayan Warmada ${ }^{1}$ \\ ${ }^{1}$ Department of Geological Engineering, Universitas Gadjah Mada, Indonesia \\ ${ }^{2}$ Department of Geological Engineering, Halu Oleo University, Indonesia
}

*Corresponding author : hasriageologi@gmail.com

Telp. +62 852-4185-7853

Received: July 8, 2017. Revised : Aug 13, 2017, Accepted: Aug 20, 2017, Published: 1 Sept 2017

DOI : 10.24273/jgeet.2017.2.3.434

\begin{abstract}
Recently, in Indonesia gold exploration activities are not only focused along volcanic-magmatic belts, but also starting to shift along metamorphic and sedimentary terrains. The study area is located in Rumbia mountains, Bombana Regency, Southeast Sulawesi Province. This paper is aimed to describe characteristics of alteration and ore mineralization associated with metamorphic rock-related gold deposits. The study area is found the placer and primary gold hosted by metamorphic rocks. The gold is evidently derived from gold-bearing quartz veins hosted by Pompangeo Metamorphic Complex (PMC). These quartz veins are currently recognized in metamorphic rocks at Rumbia Mountains. The quartz veins are mostly sheared/deformed, brecciated, irregular vein, segmented and relatively massive and crystalline texture with thickness from $1 \mathrm{~cm}$ to $15.7 \mathrm{~cm}$. The wallrock are generally weakly altered. Hydrothermal alteration types include sericitization, argillic, inner propylitic, propylitic, carbonization and carbonatization. There some precious metal identified consist of native gold and ore mineralization including pyrite $\left(\mathrm{FeS}_{2}\right)$, chalcopyrite $\left(\mathrm{CuFeS}_{2}\right)$, hematite $\left(\mathrm{Fe}_{2} \mathrm{O}_{3}\right)$, cinnabar $(\mathrm{HgS})$, stibnite $\left(\mathrm{Sb}_{2} \mathrm{~S}_{3}\right)$ and goethite $\left(\mathrm{FeHO}_{2}\right)$. The veins contain erratic gold in various grades from below detection limit $\varangle 0.0002 \mathrm{ppm}$ to $18.4 \mathrm{ppm}$. Based on those characteristics, it obviously indicates that the primary gold deposit present in the study area is of orogenic gold deposit type. The orogenic gold deposit is one of the new targets for exploration in Indonesia.
\end{abstract}

Keywords: Alteration, Ore Mineralization, Metamorphic Rocks, Gold Deposits, Rumbia mountains, Southeast Sulawesi

\section{Introduction}

Gold is one of the most malleable, ductile, dense, conductive, nondestructive, brilliant, and beautiful of metals. This unique set of qualities has made it a coveted object for most of human history in almost every civilization, and there have been active gold markets for over 6000 years (Green, 2007 in O'Connor et al., 2015), so many research and mining companies are trying to find economical gold reserves to explore.

Currently, gold exploration activities in Indonesia are focused on volcanic-hosted hydrothermal deposit. Several gold deposits were discovered are Erstberg, Kucing Liar, Deep Ore Zone (DOZ) in Papua including skarn type; Batu Hijau in Sumbawa Island (Idrus et al., 2007; Imai \& Ohno, 2005) and Grasberg in Papua including porphyry type ; Pongkor in West Java (Warmada, 2003), Gosowong in Halmahera Island including epithermal type. In Sulawesi Island, gold is also predominantly related to volcanic rocks, which are extended along western and northern Neogene magmatic arcs of the island (Idrus, 2009) (Fig. 1).

However, were recently in Indonesia gold exploration activities are not only focused along volcanic-magmatic belts, but also starting to shift along metamorphic and sedimentary terrains. Many current discoveries of placer (secondary) and primary gold mineralization genetically occur in association with metamorphic rocks, for instance, Langkowala area and Wumbubangka mountaints, Bombana in Southeast Sulawesi (Idrus \& Prihatmoko, 2011; Idrus, et al., 2011; Idrus et al., 2012), Awak Mas in South Sulawesi (Querubin \& Walters, 2011 in Idrus et al., 2014); Poboya LS-epithermal in Central Sulawesi (Wajdi et al., 2011 in Idrus et al., 2014) and Gunung Botak in Buru Island, Mollucas (Idrus et al., 2014). Gold-bearing quartz veins are also recognized in Derewo metamorphic belt at northern and northwestern part of Central Range Papua. Some exploration reports categorized the Derewo metamorphic-related quartz veins into mesothermal gold deposit type (Idrus et al., 2014). The gold mineralization genetically occur in association with sedimentary rocks is Paningkaban, Banyumas Regency, Central Java (Idrus et al., 2015).

Rumbia mountaints (Fig. 2) is one of the location having a potential of mineral resources gold has been found in southeast Sulawesi. The gold is not associated with volcanic rock-related gold deposits but associated with metamorphic rocks. This 
research aims to explore the characteristics of hydrothermal alteration and mineralization hosted by metamorphic rocks at Rumbia mountains by the aplication petrography, ore microscopic, (X-Ray Diffraction) and FA-AAS (Fire Assay-Atomic Absorption Spectrophotometry) analyses. This study is an important stage for the next exploration of gold in the area or other areas that have an identical setting of geology. Metamorphic rockhosted gold deposits could represent the new targets for gold exploration particularly in Indonesia.

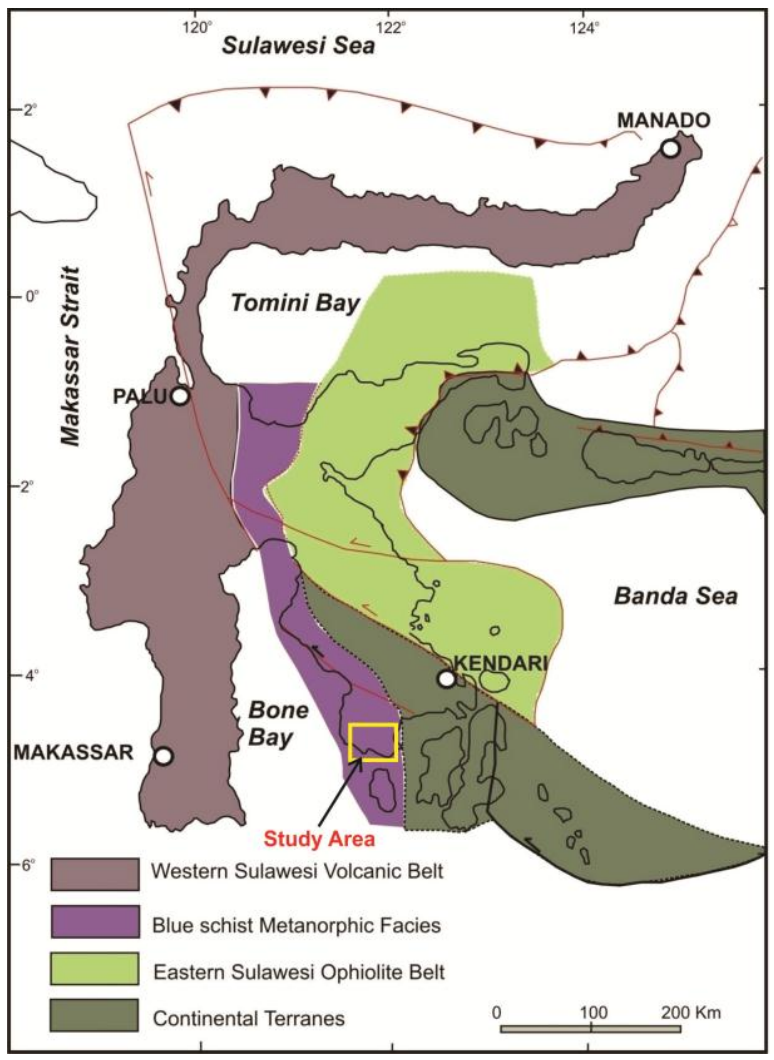

Fig. 1. Geological setting of Sulawesi Island and location of the researched area in Rumbia mountains (squared area), Southeast Sulawesi (modified from Surono, 2013).

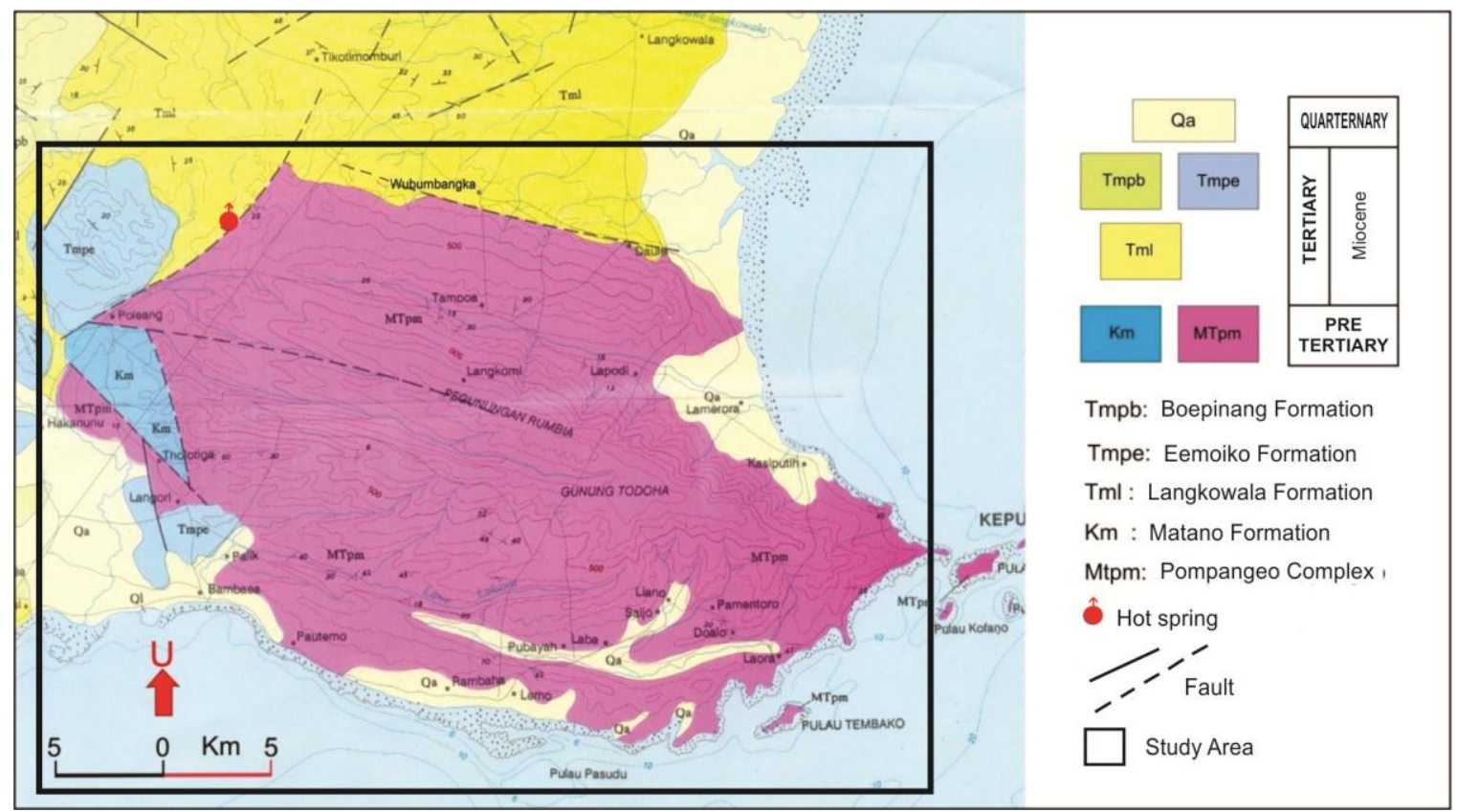

Fig. 2. Geological Geological map of Rumbia mountains area occupied by Paleozoic metamorphic rocks (Pompangeo Complex; Mtpm) (Modified from Simandjuntak et al., 1993). Squared area indicates the location area of this study. 


\section{Geological Setting}

The stratigraphy in the southeastern arm of Sulawesi consists of three constituent rocks are Sulawesi Molasse composed of clastic sediments and carbonate, ophiolite complex are dominated by mafic and ultramafic rocks and continental terrain composed of metamorphic rocks. Contaccts between the ophiolite complex and continental terrain, including their basement rocks are faulted. The Sulawesi Mollase uncorformably overlies both the ophiolite complex and continental terrain (Surono, 2013). The mountains Rumbia is a part of continental terrain is subsequently occupied by metamorphic rocks (Pompangeo Complex, Mtpm) consisting of mica schist, quartzite, glaucophane schist and chert. The continental terrain, which were firstly described by Surono, 1994. The metasediments and metamorphic rocks are of Permian-Carboniferrous in age and occupy the Mendoke and Rumbia Mountains. Mica schist and metasediments particularly meta-sandstone and marble are commonly characterized by the presence of quartz veins various width up to 2 meters, containing gold in some places (Idrus et al., 2011).

The Langkowala Formation is unconformably underlain by Paleozoic metasediments and metamorphic rocks (Pompangeo Complex, Mtpm) and conformably overlain by the Eemoiko Formation (Tmpe), which is composed of corraline limestone, calcarenite, marl and sandstone; and Boepinang Formation (Tmpb), which is composed of sandy claystone, sandy marl and sandstone. The Eemoiko and Boepinang Formations were reported having Pliocene age (Surono, 2013).

\section{Research Methods}

Field investigation was carried out in Rumbia mountaints area of Southest Sulawesi. The samples consist of altered rock, veins and clay samples collected from different hydrothermal alteration zones and ore samples. This study is conducted in four stages including field work, laboratory analyses, data analyses and interpretation. Fieldwork includes mapping of surface geology, alteration and ore mineralization as well as sampling of representative rock types, altered rocks and gold bearing veins. Laboratory work includes slab, vein textural dan structural analyses and mineralogy (petrography, ore microscopy and XRD (X-Ray diffraction) and ore geochemistry. Mineralogical analysis was conducted at Department of Geological Engineering, Gadjah Mada University and ore geochemistry was done at AAS laboratory, ALS Canada Ltd in Canada and PT. Intertek Utama Services Jakarta.

\section{The Quartz Vein}

The quartz veins in the study area consist three generations. The first is parallel to the foliations, the second crosscuts the first generation of veins/foliations, and the third is of laminated deformed quartz+calcite veins at the late stage (Fig. 3). Gold grades in the second and third veins are relatively higher than that in first veins (Table 1 ). Characteristics of quartz veins are mostly sheared/ deformed, irregular vein, brecciated, and relatively massive with thickness from $1 \mathrm{~cm}$ to $15.7 \mathrm{~cm}$. Based on data shows that gold-bearing quartz (Qz) veins/veinlets have been discovered in association with Paleozoic metamorphic rocks particularly mica schist, actinolite schist (green schist), phyllite and metasandstone.
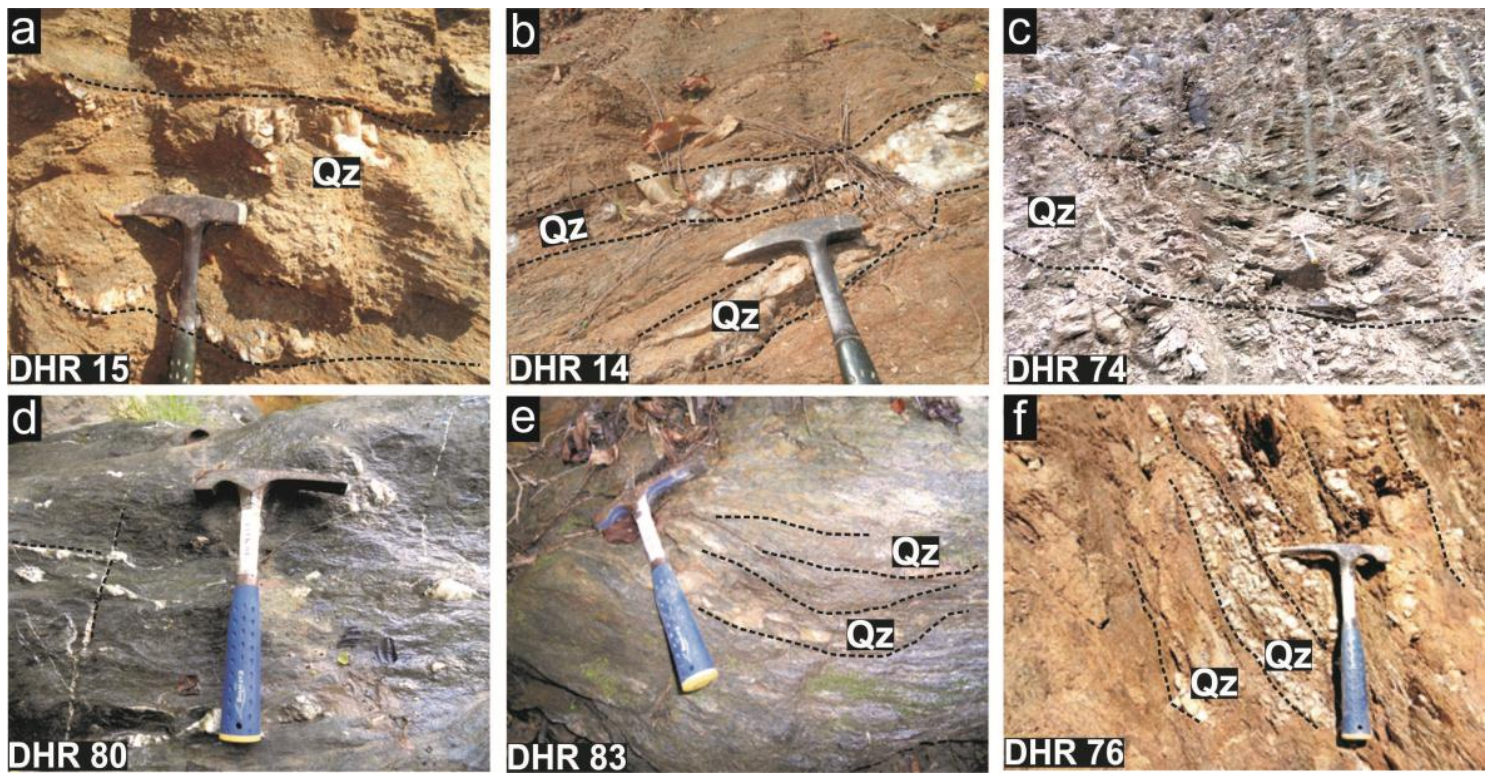

Fig. 3. Characteristics of quartz vein: (a). Brecciated, sheared/deformed quartz vein (first generation) parallel to the foliation b) massive, crystalline of quartz vein, (first generation) which is parallel to the foliation, c) brecciated, sheared/ deformed quartz vein (second generation) d). irregular vein, sheared/segmented of quartz vein cross cutting foliation (second generation), (e) A cluster of sheared/deformed laminated quartz vein (third generation), (f) laminate quartz vein (third generation). 
In addition, as observed by Prihatmoko et al. (2010), druzy/sugary and some pseudomorph bladed carbonate textures have also been recognized associated with quartz veins/reefs cross cutting foliation. In the Onggomate hill the veins formed a breccias zone composed of quartz as matrix, massive to crystalline, crackle to mosaic, with mica schist and phyllite fragments. In the Roko-Roko hill quartz veins (1-30 cm) hosted by mica schist and metasediment are commonly massive to crystalline quartz (druzy textures) with pseudomorph bladed carbonate textures. Therefore, at least 2 later stages of veinings (after the first generation veinings) could be identified, including (1) vein breccias and (2) later quartz veinlets, 1-10 mm, which are commonly crystalline and containing native gold (Prihatmoko et al., 2010 in Idrus et al, 2012 ).

\section{Hydrothermal Alteration}

Hydrothermal alteration and mineralization underlie within all lythologic units found in the research area. Widespread zones of hydrothermal alteration are found on the surface. Alteration is typically pervasive and selective pervasive with intensity ranges from weak to strong, so it is very rare to observe good outcrops in the area. In general, the wallrocks are weakly altered. Strong alteration zone is only restricted surrounding quartz veins (like halos/selvage). There are six main alteration zones that are indentified, namely sericitization, argillic, inner propylitic, propylitic, carbonatization and carbonization alterations. Sericitization is characterized by the presence of sericite (or muscovite), chlorite and quartz while argillic alteration is typified by montmorilonit-kaolinite, chlorite and quartz. Inner propylitic alteration is characterized by actinolite, chlorite, quatz and epidot, while propylitic alteration is typified epidote and/or chlorite and calcite. Carbonization is probably represented by (rare) occurrence of graphite with commonly black in colour in the quartz vein and altered mica schist and carbonatization altera-tion is typified by the presence of calcite veinlets/stringers while (Fig. 4). Ore mineralization is closely associated with seritisization, argillic, inner propylitic, propylitic and weak carbonation alterations.

The carbonization is considered to be one of the alteration type characteristics, associated with orogenic/ metamorphic-hosted gold deposit (Idrus, et al., 2012). Idrus et al. (2012) al so reported the presence silicification alteration is represented by silicified metasediment and mica schist mostly present surrounding quartz veins or along structural zones. The presence of narrow clay-sericite alteration halo (tens $\mathrm{cm}$ to $1 \mathrm{~m}$ ) around the quartz veins in the RokoRoko hill (Prihatmoko et al., 2010 in Idrus et al., 2012).
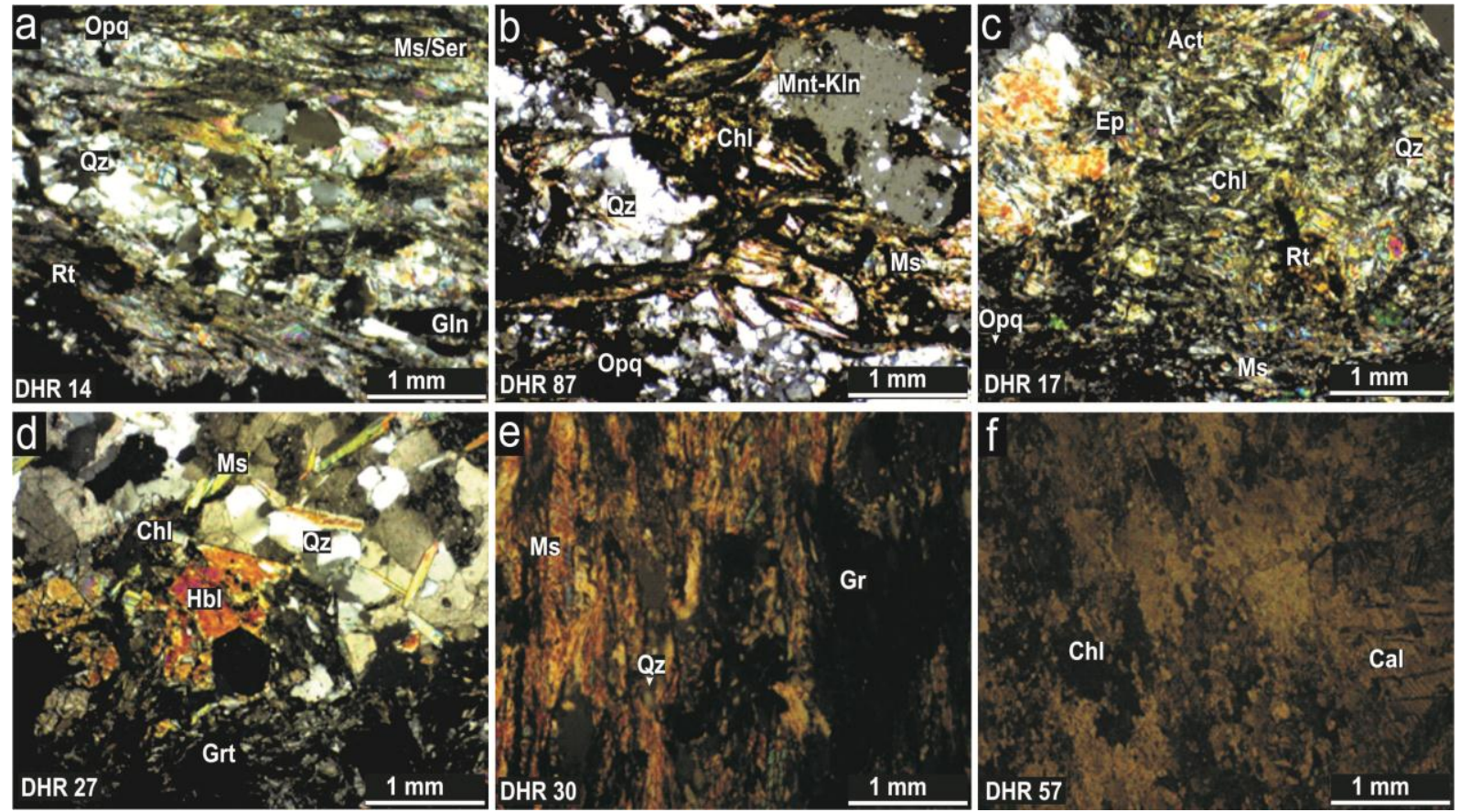

Fig. 4. Hyrdothermal alteration types: (a). Sericitization, (b). Argillic, (c). Inner propylitic, (d). propylitic, (e). Carbonization,(f Carbonatization alteration. The scale bar without expression in each of photomicrograph on this paper indicates $1 \mathrm{~mm}$. $\mathrm{x}$ nicol 40x. Opq=opaq, $m s=$ Muscovite, Ser= sericite, $Q z=$ quartz, $R t=$ rutil, $G l n=$ glaucophane, $M n t-K l n=$ montmorilonitekaolinite, $\mathrm{Chl}=$ chlorite, $\mathrm{Ep}=$ epidote, $\mathrm{Act}=$ actinolite, $\mathrm{Hbl}=$ hornblende, $\mathrm{Grt}=$ garnet, $\mathrm{Gr}=$ graphite, Cal=cal cite. 


\section{Ore Mineralization}

Based on field relationship, ore microscopy, electron microprobe analyses, there some precious metal identified consist of native gold and ore mineralization including pyrite (FeS2), chalcopyrite (CuFeS2), hematite (Fe2O3), cinnabar (HgS), stibnite (Sb2S3) and goethite (FeHO2). Idrus et al. (2012) also reported the presence tripuhyite (FeSbO4) and rare arsenopyrite (FeAsS2) are present in the quartz veins and silicified metamorphic wallrocks.

Pyrite, hematite, cinnabar and stibnite are present abundantly in the primary mineralization gold deposits, present in the quartz veins and wallrocks; and commonly present at alteration rocks (Fig. 5). Pyrite occurs as isolated idiomorphic crystals, angular fragmens, strongly brecciated fragments, anhedral shape, medium reflectance and isotropic. Some pyrite grains are partly enclosed by hematite, chalcopyrite and possibly stibnite. Fractures and brittle cavities in pyrite are often filled by hematite and chalcopyrite. Hematite is typically pinkish orange in color and commonly present in altered rocks, internal purple reflections, subhedral-anhedral crystals, present as sulfide mineral interactions with oxygen causing the oxidation of sulphide minerals, especially pyrite. Hematite is looked replacing pyrite.

Chalcopyrite is associated with pyrite while cinnabar is typically pinkish red in color and commonly occurred in the form of mineralized layers along foliations of the metamorphic rocks.

Pyrite, hematite, cinnabar and stibnite are genetically closely related to gold mineralization. Graphite (Gr) is present as a result of carbonization and associated with stibnite minerals.

Those sulfides could be pathfinder minerals for the exploration of the metamorphic-hosted gold deposit. In general, gold is very fine-grain, but occasionally native gold is visible in quartz veins.

Bulk-ore chemistry analyzed by AAS (Atomic Absorption Spectrometry) indicates a very broad and erratic variation of gold grade ranging from below detection limit $\varangle 0.0002$ ppm to 18.4 ppm Au (Table 1 ).
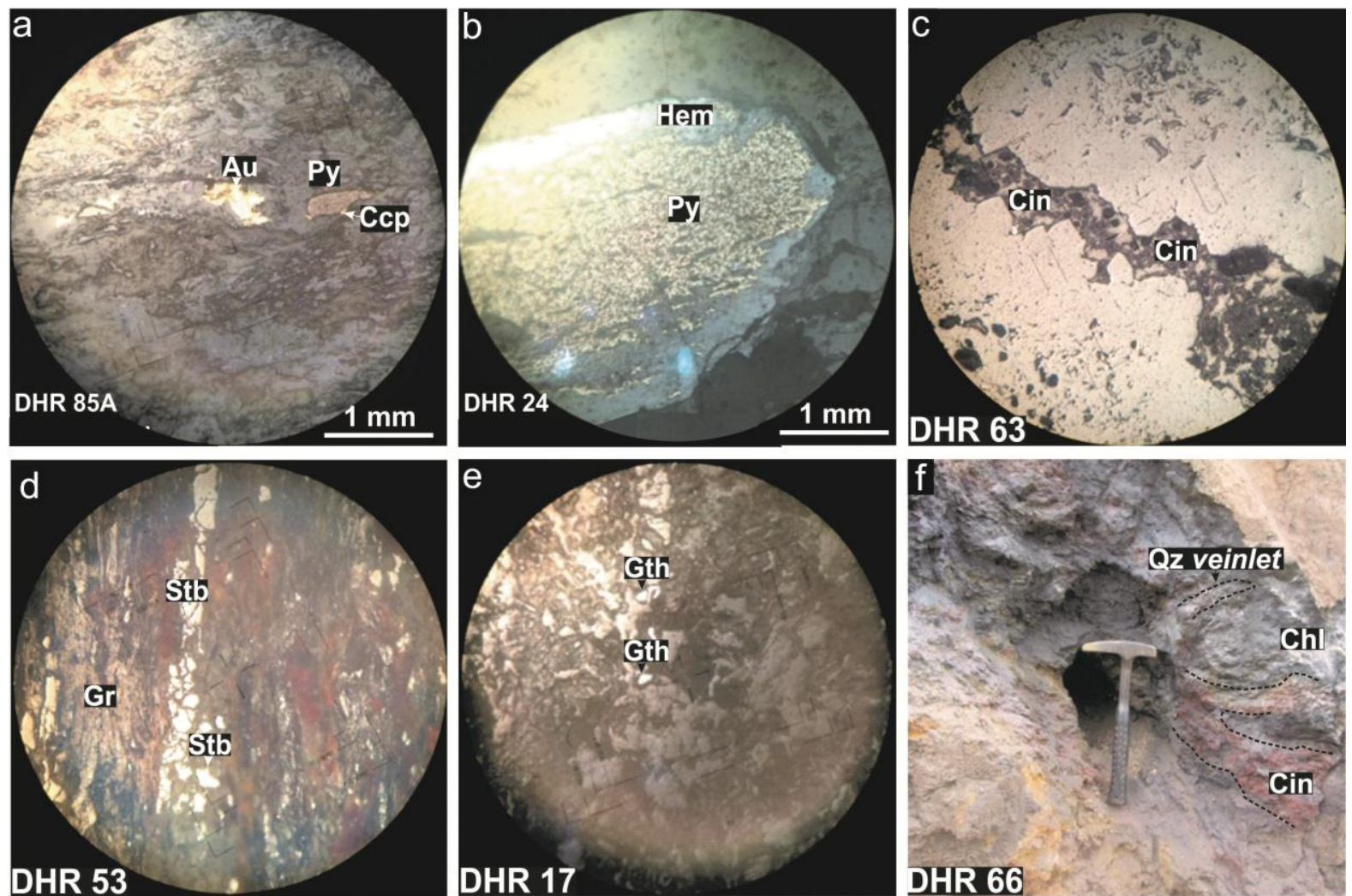

Fig. 5. Ore minerals in study area. a. Aurum? (gold?), pyrite and chalcopyrite. b. Hematite is looked replacing pyrite. c and $f$ The present of abundantly cinnabar in mineralization of hydrothermal gold deposits. d. Graphite as a result of carbonization and associated with stibnite. e. Goethite. The scale bar without expression in each of photomicrograph on this paper indicates $1 \mathrm{~mm}$. Au=aurum (gold), Py=pyrite, $\mathrm{Ccp}=$ chalcopyrite, Hem=hematite, Cin=cinnabar, Stb= stibnite, Gth=goethite, Qz= quartz,Chl=chlorite.. 
Table 1. Ore geochemistry of metamorphic-hosted gold quartz veins/reefs from Rumbia mountains, Bombana (in ppm).

\begin{tabular}{|c|c|c|c|c|c|c|c|c|}
\hline \multirow{2}{*}{$\begin{array}{l}\text { Samples } \\
\text { code }\end{array}$} & \multicolumn{8}{|c|}{ Elements (ppm) } \\
\hline & $\mathrm{Au}$ & $\mathrm{Ag}$ & As & $\mathrm{Cu}$ & $\mathrm{Hg}$ & $\mathrm{Pb}$ & $\mathrm{Sb}$ & $\mathrm{Zn}$ \\
\hline DHR 11 & 0.0007 & 1.170 & 0.69 & 17.15 & 0.007 & 29.9 & 3.86 & 45.2 \\
\hline DHR 15 & 0.0007 & 0.232 & 2.53 & 45.1 & 0.021 & 8.22 & 0.975 & 56.1 \\
\hline DHR 16 & $\varangle 0.0002$ & 1.620 & 4.22 & 71.8 & $\varangle 0.004$ & 29.3 & 7.33 & 66.8 \\
\hline DHR 20 & $\varangle 0.0002$ & 0.138 & 3.85 & 31.7 & 0.072 & 13.20 & 0.675 & 47.1 \\
\hline DHR 24 & 0.0004 & 1.420 & 5.38 & 28.1 & 0.013 & 48.2 & 6.85 & 87.9 \\
\hline DHR 25 & 0.0008 & 0.161 & 5.35 & 13.75 & 0.005 & 8.18 & 1.285 & 12.7 \\
\hline DHR 34 & 0.0048 & 0.619 & 27.800 & 123.50 & 0.015 & 24.40 & 2.460 & 34.7 \\
\hline DHR 35A & 0.0779 & 0.093 & 194.500 & 7.70 & 0.577 & 4.22 & 19.600 & 4.3 \\
\hline DHR 50 & 0.0017 & 0.650 & 1810.00 & 43.00 & 1.375 & 83.00 & 6170.000 & 109.5 \\
\hline DHR 55 & 0.0124 & 0.014 & 49.100 & 61.90 & 0.287 & 11.15 & 1.795 & 59.5 \\
\hline DHR 62 & 0.0049 & 0.405 & 17.500 & 7.79 & 0.065 & 11.40 & 28.000 & 12.3 \\
\hline DHR 66 & 0.0071 & 0.191 & 160.00 & 708.00 & 0.085 & 10.10 & 3.210 & 138.5 \\
\hline DHR 74B & 0.0009 & 0.491 & 2.52 & 4.70 & 0.010 & 19.45 & 5.060 & 10.8 \\
\hline DHR 76A & 0.0009 & 0.103 & 3.23 & 17.70 & 0.076 & 19.35 & 0.733 & 48.4 \\
\hline DHR 81A & 0.0014 & 0.564 & 32.4 & 179.00 & 0.014 & 9.10 & 2.060 & 61.3 \\
\hline DHR 85A & 0.0024 & 3.100 & 2.44 & 1505.00 & 0.020 & 3.99 & 0.739 & 59.4 \\
\hline DHR 87 & 0.0002 & 0.281 & 2.88 & 1150.00 & 0.010 & 8.44 & 6.300 & 11.8 \\
\hline DHR 87A & 0.0015 & 0.112 & 4.11 & 30.80 & 0.032 & 24.4 & 0.635 & 27.9 \\
\hline DHR 97A & $\varangle 0.0002$ & 0.041 & 4.48 & 51.00 & 0.011 & 4.68 & 1.835 & 39.9 \\
\hline DHR 101 & 0.7200 & 0.300 & 1840.00 & 43.00 & 0.080 & 6.00 & 21.000 & 53.0 \\
\hline DHR 103 & 0.0800 & 0.100 & 69.00 & 26.00 & 0.210 & 2.00 & 2.000 & 14.0 \\
\hline DHR 104 & 18.4000 & 0.300 & 192.00 & 44.00 & 0.310 & 27.00 & 62.000 & 52.0 \\
\hline DHR 105 & 0.9800 & $<0.010$ & 292.00 & 23.00 & 0.150 & 28.00 & 17.000 & 49.0 \\
\hline DHR 107 & 3.7600 & 0.100 & 852.00 & 25.00 & 0.340 & 11.00 & 37.000 & 42.0 \\
\hline DHR 108 & 0.2600 & 0.100 & 201.00 & 44.00 & 0.440 & 9.00 & 148.000 & 57.0 \\
\hline DHR 109 & 0.6300 & $<0.100$ & 118.00 & 28.00 & 0.070 & 9.00 & 32.000 & 53.0 \\
\hline DHR 110 & 0.1500 & 0.300 & 279.00 & 43.00 & 0.290 & 18.00 & 160.000 & 77.0 \\
\hline DHR 111 & 0.2200 & 0.100 & 75.00 & 45.00 & 0.080 & 11.00 & 34.000 & 20.0 \\
\hline DHR 113 & $<0.0100$ & 0.100 & 18.00 & 15.00 & 0.430 & $<2.00$ & 7.000 & 11.0 \\
\hline
\end{tabular}

\section{Conclusion}

The primary gold grains hosted by Rumbia mountains are evidently derived from sheared and segmented, partly brecciated, relatively massive, laminated gold-bearing quartz \pm calcite veins/reefs with thickness from $1 \mathrm{~cm}$ to $15.7 \mathrm{~cm}$ hosted by Pompangeo Metamorphic Complex (PMC). The PMC particularly consists of mica schist (dominant rock type), actinolite schist, phyllite and metasedimen. Mica schist is abundantly composed of muscovite, chlorite quartz, actinolite, epidote with a small amount of, sericite, rutile, kyanite and opaque minerals. Hence, the metamorphic rock is categorized into green schist facies, which is noted as an important host rock facies for orogenic gold deposit worldwide

The metamorphic rocks are strongly weathered, however trenching program has opened up the soil cover and exposes the hydrothermal alteration zones. In general, the wallrocks are weakly altered. Hydrothermal alteration types include sericitization, argillic, inner propylitic, propylitic, carbonatization and carbonization. The veins contain erratic gold in various grades from below detection limit limit $\varangle 0.0002 \mathrm{ppm}$ to $18.4 \mathrm{ppm}$. Mineralogically, gold is genetically related to consist of pyrite (FeS2), chalcopyrite (CuFeS2), hematite (Fe2O3), cinnabar (HgS), stibnite (Sb2S3) and goethite (FeHO2). Idrus et al. (2012) also reported the presence tripuhyite (FeSbO4) and rare arsenopyrite (FeAsS2) are present in the quartz veins and silicified metamorphic wallrocks. Gold is mainly identified in the form of 'free gold' among silicate minerals particularly quartz. Based on those characteristics, it obviously indicates that the primary gold deposit present in the study area is of orogenic gold deposit type (cf. Groves et al., 1998; 2003 and Goldfarb et al., 2005). The orogenic gold deposit is one of the new targets for exploration in Indonesia.

\section{Acknowledgements}

This study was funded by RISTEKDIKTI research grant 2017 awarded to the author. Fieldwork was partly supported by PT. Panca Logam Makmur (PLM) which has given us permission to do this research in the Wumbubangka prospect area and its vicinity. Special thanks to my students from Department of Geological Engineering, Halu Oleo University for their assistance during the fieldwork. Weal so would like to thank the Head and staff the Geological Engineering 
Department, Faculty of Engineering, Gadjah Mada University who gave me permission to access to the laboratories.

\section{References}

Goldfarb, R.J., Baker, T., Dube, B., Groves, D.J., Hart, C.J.R., and Gosselin, P., 2005. Distribution character and genesis of gold deposits in metamorphic terrains. In: Hedenquist, J.W., Thompson, J.F.H., Goldfarb, R.J., Richards, I.P (Eds.), Economic Geology. One Hundred ${ }^{\text {th }}$ Anniversary Volume, p. 407-450.

Groves, D. I., Goldfarb, R. J., and Robert, F., 2003. Gold deposit in metamorphic belts: Overview or current understanding, outstanding problems, future research, and exploration significance. Economic Geology, 98, p.1-29.

Groves, D. I., Goldfarb, R. J., Gebre-Mariam, M., Hagemann, S. G., and Robert, F., 1998. Orogenic gold deposit: A proposed classification in the context or their crustal distribution and relationship to other gold deposit types. Ore Geology Review, 13, p.7-27.

Idrus, A., 2009. Potensi Sumberdaya Mineral Bijih pada Busur Magmatik Sulawesi bagian Barat dan Utara, Invited speaker on National Seminar "Geologi Sulawesi dan Prospeknya", Makassar, 3 Oktober 2009, 26pp.

Idrus, A., Fadlin., Prihatmoko, S., Warmada, I.W., Nur, I., and Meyer, F.M., 2012. The metamorphic rockhosted gold mineralization at Bombana, Southeast Sulawesi: a new exploration target in Indonesia. Jurnal Sumber Daya Geologi, (22) 1: 35-48.

Idrus, A., Hakim, F., Warmada, I.W., Aziz, M., Kolb, M and Meyer, F.M., 2015. Geology and ore mineralization of Neogene sedimentary rock hosted LSepithermal gold deposit at Paningkaban, Banyumas Regency, Central Java, Indonesia.Journal of Southeast Asian Applied Geology,Volume 7(2), pp. 73-79.

Idrus, A., Kolb, J., and Meyer, F.M., 2007. Chemical composition of rock-forming minerals in copper- gold- bearing tonalite porphyry intrusions at the Batu Hijau deposit, Sumbawa Island, Indonesia: Implications for crystallisation conditions and fluorine-chlorine fugacity, Special Issue. Resource Geology, 57 (2), p.102-113.

Idrus, A., Nur, I., Warmada, I W., and Fadlin., 2011. Metamorphic rock-hosted orogenic gold deposit type as a source of Langkowala placer gold, Bombana, Southeast Sulawesi. Jurnal Geologi Indonesia, (6) 1: 43-49.

Idrus, A., Prihatmoko, S., Hartono, GH., Idrus., Ernowo, Franklin, Moetamar, Setiawan, I., 2014. Some Key Features and Possible Origin of the etamorphic Rock-Hosted Gold Mineralization in Buru Island, Indonesia. Indonesian Journal on Geoscience, 1, p. 9-19.

Imai, A. and Ohno, S., 2005. Primary ore mineral assemblage and fluid inclusion study of the Batu Hijau porphyry Cu-Au deposit, Sumbawa, Indonesia. Resource Geology, 55, p.239-248.

O'Connor, F.A., Lucey, B.M., Batten, J.A., and Baur, D.G., 2015. The financial economics of gold-A survey. International Review of Financial Analysis, 1-20p.

Simandjuntak, T.O., Surono, and Sukido., 1993. Peta Geologi Lembar Kolaka, Sulawesi, skala 1 : 250.000. Pusat Penelitian dan Pengembangan Geologi, Bandung.

Surono., 2013. Geologi Lengan Tenggara Sulawesi. Badan Geologi, Kementerian Energi dan Sumber Daya Mineral. Bandung, 169p.

Wadji, M.F., Santoso, S.T.J., Kusumanto, D., and Digdowirogo, S., 2011. Metamorphic Hosted Low Sulfidation Epithermal Gold System at Poboya, Central Sulawesi : A General Descriptive Review, Proceedings of The Sulawesi Mineral Seminar, Manado 28-29 November 2011, p. 201-210.

Warmada, I W., 2003. Ore mineralogy and geochemistry of the Pongkor epithermal goldsilver deposit, Indonesia. Dissertation. Papierflieger, Clausthal-Zellerfeld. ISBN: 3-89720658-7. 